\title{
Efficacy of NETDC (New England Trophoblastic Disease Center) prognostic index score to predict gestational trophoblastic tumor from hydatidiform mole
}

\author{
Khrismawan ${ }^{*}$, Agustria Zainu Saleh", Rizal Sanif*, Theodorus ${ }^{* *}$
}

\begin{abstract}
Abstrak
Penelitian longitudinal prospektif analitik untuk menilai ketepatan prediksi timbulnya penyakit trofoblas ganas melalui sistem penilaian prognosis mola hidatidosa yang dikembangkan oleh NETDC (New England Trophoblast Disease Center) telah dilakukan. Di antara parameter faktor risiko yang dinilai; usia penderita, jenis mola hidatidosa, pembesaran uterus, kadar hCG serum, kista lutein, serta adatidaknya komplikasi merupakan factor risiko yang bermakna untuk timbulnya keganasan setelah mola hidatidosa dievakuasi $(p=0,032)$. Penelitian dilakukan pada 50 penderita mola hidatidosa dengan pengamatan lanjutan selama 1 tahun (Januari 2001-Desember 2002) di Bagian Obstetri dan Ginekologi RS Mohammad Hoesin, Palembang. Hasilnya menunjukan prediksi keganasan skor NETDC 50\% pada risiko tinggi dan $10 \%$ risiko rendah untuk berkembang menjadi ganas $(p<0,05)$. Hasil ini lebih besar dibandingkan dengan nilai yang diajukan WHO yaitu 19-30\%. Risiko untuk terjadinya keganasan pasca mola hidatidosa pada kelompok risiko tinggi ialah 9,0 kali lebih tinggi disbanding pada kelompok risiko rendah (CI: 1,769-45,786). (Med J Indones 2004; 13: 40-6)
\end{abstract}

\begin{abstract}
A prospective longitudinal analytic study assessing the efficacy of NETDC (New England Trophoblastic Disease Center) prognostic index score in predicting malignancy after hydatidiform mole had been performed. Of the parameter evaluated; age of patients, type of hydatidiform mole, uterine enlargement, serum hCG level, lutein cyst, and presence of complicating factors were significant risk factors for malignancy after hydatidiform mole were evacuated ( $p<0.032$ ). The study were done on 50 women diagnosed with hydatidiform mole with 1 year observation (January 2001-December 2002) at the Department of Obstetrics and Gynecology, Mohammad Hoesin Hospital, Palembang. The results showed that the NETDC prognostic index score predicted malignancy in 50\% of high risk group and 10\% in low risk group (p<0.05). This showed a higher number than that found by the WHO (19\%-30\%). The risk for incidence of malignancy after hydatidiform mole in the high risk group is 9.0 times higher compared to that of the low risk group (CI: 1.769-45.786). (Med J Indones 2004; 13: 40-6)
\end{abstract}

Keywords: New England Trophoblastic Disease Center (NETDC), gestational trophoblastic tumor, hydatidiform mole, high and low risk.

Gestational trophoblastic tumors (GTTs) are rare but highly curable tumors arising from the products of conception in the uterus. The prognosis for cure of patients with GTTs is good even when the disease has spread to distant organs, especially when only the lungs are involved. The probability of cure depends on the histologic type (mole, invasive mole, or choriocarcinoma), the extent of spread of the

\footnotetext{
* Department of Obstetrics and Gynecology, Faculty of Medicine, Sriwijaya University, Palembang, Indonesia

** Department of Epidemiology, Faculty of Public Health, Sriwijaya University, Palembang, Indonesia
}

disease, the level of the human chorionic gonadotropin (hCG) titer, the duration of disease from initial pregnancy event to start of treatment, the specific sites of metastases, the nature of antecedent pregnancy, and the extent of prior treatment. Selection of treatment on these factors plus the patient's desire for future pregnancies. Human chorionic gonadotropin, produced normally during pregnancy, is abnormally elevated in the blood and urine of patients with this group of diseases and is a sensitive marker to indicate the presence or absence of disease before, during and after treatment. ${ }^{1,2}$

The most common antecedent pregnancy is that of a hydatidiform mole, usually a genetic disorder of 
pregnancy in which only placental-like tissue is present. The patient will present with abnormal bleeding from onset of pregnancy and may have a uterus which is much larger than expected. Sonography is the preferred method of diagnosis, and suction curettage is the preferred method of evacuation. Of most importance is careful follow-up with serum beta HCG ( $\beta$ hCG) weekly until less than $100 \mathrm{mIU} / \mathrm{mL}$ and then every two weeks. The patient should have a careful pelvic examination every other week and a chest x-ray every 4-6 weeks. Once the titer of serum BhCG has fallen to normal levels, these two examinations need no longer be done; however, $\beta \mathrm{hCG}$ titers need to be repeated every 2 weeks for 3 months, then monthly for 3 months, then every 2 months for 6 months, then every 6 months for 3 years. Each patient should be counseled in the use of a reliable birth control method. Any patient who develops an increasing level of serum $\beta$ hCG, a plateau of the $\beta$ hCG over 3 weeks, or persistent elevation of $\beta \mathrm{hCG}$ after 16 weeks of follow-up should be considered as having gestational trophoblastic tumor and should undergo the appropriate work-up and treatment. Similarly, any patient who develops metastatic disease during follow-up should be staged and undergo treatment. ${ }^{2,3}$

Various classification systems for gestational trophoblastic tumors (GTTs) have been applied. An anatomical staging system has been adopted by FIGO (International Federation of Gynecology and Obstetrics). In addition, the NETDC (New England Trophoblastic Diseases Centre) has proposed a prognostic scoring system for the determination of therapy. There has, however, been a lack of uniformity in the use of these systems.

\section{MATERIAL AND METHODS}

This study includes patients with hydatidiform mole diagnosed in Mohammad Hoesin Hospital Palembang, from January 2001 to December 2002. The patients divided into high and low risk for NETDC prognostic score with determining factors were type of hydatidiform mole, uterine enlargement, lutein cyst, age and abcent or present factors correlated with hydatidiform mole. The patients with hydatidiform mole included in this study were those evacuated at Dr. Moh. Hoesin Hospital. Before that the patients will take the blood sample for $\beta \mathrm{HCG}$ serum examination and other clinical and laboratory examination to determine high and low risk. The patient will be closely follow up for a year to observe malignancy after hydatidifom mole evacuated.

We computed relative risk as estimators of high and low risk, together with their 95\% approximate confidence interval. A $\chi^{2}$ test was used to compare the distribution of various patient characteristics in the two risk score group. Logistic regresion will be determine what is the factor was influence to malignancy. A significance level of .05 was chosen. However, because adjustment for most covariates and important prognostic score in NETDC score, we present estimates high and low risk for occur malignancy after evacuated hydatidiform mole. The data were analyzed using the program package SPSS 11.5 for windows.

Table 1. Characteristics

\begin{tabular}{lccc}
\hline & \multicolumn{2}{c}{ Risk criteria } & $\rho^{*}$ \\
\cline { 2 - 3 } Characteristics & High & Low & 0.011 \\
Age (years) & $31.97 \pm 8.43$ & $26.15 \pm 6.06$ & 0.031 \\
Parity & $2.37 \pm 1.94$ & $1.25 \pm 1.37$ & 0.023 \\
Size of corpus uterine (in weeks) & $19.53 \pm 3.92$ & $16.90 \pm 3.80$ & 0.024 \\
T 3 (ng/ml) & $2.51 \pm 1.11$ & $1.79 \pm 1.00$ & 0.008 \\
T 4 (ng/dl) & $18.87 \pm 6.95$ & $13.23 \pm 7.19$ & 0.001 \\
Human chorionic gonadotropin (mIU/ml) & $56,863.50 \pm 53,722.77$ & $16,793.09 \pm 25,181.70$ & 0.015 \\
Wayne index & $11.46 \pm 6.41$ & $6.95 \pm 5.78$ & 0.250 \\
Kariadi index & $0.43 \pm 3.18$ & $-1.80 \pm 8.01$ & 0.003 \\
Interval of acuteness (in months) & $5.27 \pm 7.51$ & $0.6 \pm 1.96$ & \\
\hline
\end{tabular}

* Student $t$ test. $($ mean \pm SD) Significant $\rho<0.05$ 


\section{RESULTS}

Seventy cases of hydatidiform mole (40 occurred in 2001 and 30 in 2002) and 69 cases of gestational trophoblastic tumor were diagnosed between January 2001 and December 2002. In addition, seventeen patients at the very beginning were diagnosed as having hydatidiform mole. The ratio of hydatidiform mole at Moh. Hoesin Hospital of Palembang was 1 to 43.375 deliveries and 1 to 57.45 pregnancies in 2001, and 1 to 44.3 deliveries and 1 to 64.90 pregnancies in 2002.

The average age of the patients in this study was $29.64 \pm 8.04$ years and the most dominant group was in the range of 20-35 years. Age difference average in the high risk group $(31.97 \pm 8.43$ years) and in the low risk group $(26.15 \pm 6.06$ years) showed a significant indication $(\rho<0.05)$. The average of marital duration was $8.08 \pm 7.63$ years. The high risk group showed a higher parity average of $2.37 \pm 1.94$ than that of the low risk group $(1.25 \pm 1.37)(\rho=0.031)$. Most of the patients (90\%) had low educational background, and $80 \%$ had no jobs. Their husbands also had low educational background and $48 \%$ were laborers. Thirty six patients $(72 \%)$ live in the urban areas and 14 patients (28\%) live outside the urban areas. Their sistolic blood pressure average was $125.33 \pm 17.01 \mathrm{mmHg}$ in the high risk group and $115.50 \pm 17.01 \mathrm{mmHg}$ in the low risk group. Their pulse average was $102.67 \pm 17.93$ in the high risk group and $96.20 \pm 12.56$ in the low risk group. Their breathing average was $23.07 \pm 2.77$ and $22.90 \pm 2.63$ respectively. There was no significant difference in all these variables $(\rho>0.05)$.
Based on the last menstruation period, pregnancy length of the high risk group was $12.77 \pm 4.07$ weeks ; this was a little bit higher than that of the low risk group (14.50 \pm 2.35 weeks $)(\rho>0.05)$. In contrast, in fundal height, it showed the following data $(19.53 \pm 3.9$ weeks for the high risk group and $16.90 \pm 3.81$ weeks for the low risk group) $(\rho<0.05)$. In terms of uterine fundal height, the average pregnancy length was higher than the first day of the last menstruation period $(\rho<0.05)$.

The number of patients and their husbands having $\mathrm{O}$ blood group was $52 \%$ and $38.5 \%$ became gestational trophoblastic tumor $(\rho>0.05)$. Eight patients $(33.3 \%)$ having anemia became gestational trophoblastic tumor, and nine patients $(34.6 \%)$ had no anemia. Nine patients $(10 \%)$ showed positive urine proteins, and the rest showed the negative ones. Three patients $(6 \%)$ showed positive acetone urine and 47 (94\%) did not. There were no correlation between blood group, anemia, protein urine, or acetone urine and gestational trophoblastic tumor $(\rho>0.05)$. Average T3 composition was $2.22 \pm$ $1.11 \mathrm{ng} / \mathrm{ml}$ and that of T4 was $18.87 \pm 6.95 \mathrm{ug} / \mathrm{dl}$. T3 and $\mathrm{T} 4$ contents showed differences in the high risk and low risk groups $(\rho<0.05)$. There were no significant correlation between Wayne index and the risk grouping $(\rho>0.05)$. The Index showing hyperthyroid $(57.1 \%)$ indicated that they would suffer gestational trophoblastic tumor $(\rho<0.05)$. The Kariadi index showed that 11 patients $(55 \%)$ suffering thyrotoxycosis and six patients (20\%) having euthyroid would undergo gestational trophoblastic tumor $(\rho<0.05)$ (Table 2). Pathologically, all high risk patients suffered complete hydatidiform mole, $34.7 \%$ of them experienced gestational trophoblastic tumor, and only one of them had partial hydatidiform mole $(\rho>0.05)$.

Table 2. Gestational trophoblastic tumor

\begin{tabular}{|c|c|c|c|}
\hline \multirow{2}{*}{ Characteristics } & \multicolumn{2}{|c|}{ Gestational trophoblastic tumor } & \multirow{2}{*}{$\rho^{*}$} \\
\hline & Yes & No & \\
\hline Age (years) & $32.35 \pm 8.13$ & $28.24 \pm 7.74$ & 0.087 \\
\hline Parity & $2.35 \pm 2.26$ & $1.69 \pm 1.51$ & 0.227 \\
\hline Size of corpus uterine (weeks) & $19.29 \pm 4.23$ & $18.06 \pm 3.95$ & 0.313 \\
\hline $\mathrm{T}_{3}(\mathrm{ng} / \mathrm{ml})$ & $2.62 \pm 1.11$ & $2.01 \pm 1.08$ & 0.071 \\
\hline $\mathrm{T}_{4}(\mathrm{ng} / \mathrm{dl})$ & $19.70 \pm 6.74$ & $15.02 \pm 7.47$ & 0.036 \\
\hline$\beta \mathrm{hCG}(\mathrm{mIU} / \mathrm{ml})$ & $66,615.81 \pm 54,486.64$ & $27,554.49 \pm 39,683.83$ & 0.015 \\
\hline Wayne index & $12.94 \pm 5.21$ & $7.97 \pm 6.51$ & 0.009 \\
\hline Kariadi index & $0.18 \pm 4.11$ & $-0.79 \pm 6.36$ & 0.571 \\
\hline
\end{tabular}

* Student $t$ test. Average score (mean $\pm \mathrm{SD}$ ) hCG (Human Chorionic Gonadotropin).

Significant $\rho<0.05$ 
As for $\beta$ hCG, high risk patients showed an average of $56,863.50 \pm 53,722.77 \mathrm{mIU} / \mathrm{ml}$ and the low risk ones $16,793.09 \pm 25,181.70 \mathrm{mIU} / \mathrm{ml}$ and they significantly turned into sufferers of gestational trophoblastic tumor $(\rho<0.05)$. Fifty eight percent of the patients with a $\beta$ hCG concentration of over $50,000 \mathrm{mIU} / \mathrm{ml}$ and $21.2 \%$ with that of less than $50,000 \mathrm{mIU} / \mathrm{ml}$ suffered gestational trophoblastic tumor $(\rho<0.05)$. NETDC prognostic scores obtained through a univariate regression analysis indicated that only the variable of $B \mathrm{hCG}$ serum concentration and medical factors had significant traces of the occurrence of gestational trophoblastic tumor ( $\rho$ $<0.05$ ). A further analysis showed the dominance of $\beta$ hCG only $(\rho=0.02)$. In general, the variables above had an influence in the occurrence of gestational trophoblastic tumor $(\rho=0.032)$.

Based the NETDC prognostic scores, it was found that $50 \%$ of hydatidiform mole occurred to the high risk group (a score of $\geq 4$ ) and $10 \%$ to the low risk group (a score of $<4$ ) that led to gestational trophoblastic tumor $(\rho<0.05)$. The high risk group suffered nine times higher than the low risk group (confidence interval: 1.769 - 45.786) (Table 3).
Table 3. Risks of hydatidiform mole turning into gestational trophoblastic tumor

\begin{tabular}{lrrrrr}
\hline \multirow{2}{*}{$\begin{array}{c}\text { Risks } \\
\text { grouping }\end{array}$} & \multicolumn{4}{c}{$\begin{array}{c}\text { Gestational trophoblastic } \\
\text { tumor }\end{array}$} \\
\cline { 2 - 5 } & \multicolumn{3}{c}{ Yes } & \multicolumn{3}{c}{ No } & \\
\hline High & 15 & $50.0 \%$ & 15 & $50.0 \%$ & 30 \\
Low & 2 & $10.0 \%$ & 18 & $90.0 \%$ & 20 \\
\hline & 17 & $60.0 \%$ & 33 & $40.0 \%$ & 50 \\
\hline
\end{tabular}

$\chi^{2}=8.556 \mathrm{RR}: 9.0(\mathrm{CI}: 1.769-45.786) \rho=0.003$

Average time intervals between the diagnose of hydatidiform mole and gestational trophoblastic tumor was $10.00 \pm 7.28$ months. The interval for the high risk group was $6.00 \pm 2.83$ months and the low risk group $10.53 \pm 7.57$ months $(\rho=0.426)$.

Within the 12-month observation, the high risk group showed a less survival rate than the low risk group (40\% to $50 \%$ ) but in the fifth months, the high risk group showed a higher survival rate $(86.67 \%$ to $50 \%)$. This difference cannot be statistically proved $(\rho=$ 0.710). (Figure 1).

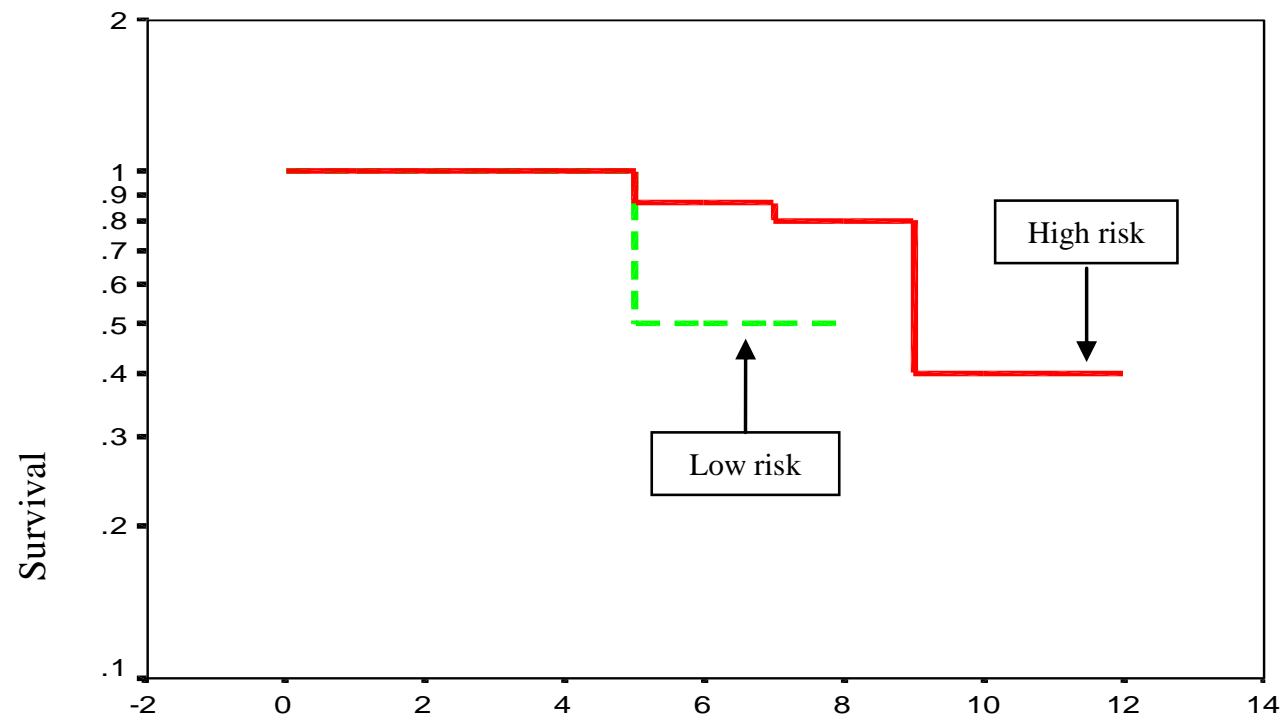

Times for being gestational trophoblastic tumor (months)

Figure 1. Bold straight lines indicate high risk criteria, and dotted lines low risk criteria 
Twenty eight percent of the patients were evacuated by curettage, $16 \%$ percent with hysterectomy and $2 \%$ curettage-hysterectomy. Thirty six point six percent of curettage cases and $25 \%$ of hysterectomy cases developed into malignancy cases $(\rho>0.05)$. It was proved that hysterectomy could not fully prevent the malignancy cases from attacking post-hydatidiform mole patients.

\section{DISCUSSION}

Determination of hCG concentration with positive reaction pregnancy test was not pathognomonic. Hydatidiform mole was suspected when the pregnancy test solution was positive at $1 / 200$. The hCG concentration was more frequently used for a prognostic factor. A hCG concentration of more than 100,000 $\mathrm{mIU} / \mathrm{ml}$ is used as one of the high risk criteria that indicates the presence of post-hydatidiform mole. ${ }^{4,5,6,8}$

Maternal age is constantly identified as a high risk factor. Presence of a specific age is depicted in the $\mathrm{J}$ curve: young age is the most dominant and the number of patients over 40 years is dramatically high. ${ }^{5,6,7}$ This research shows the most dominant group age falls between 20 and 35, 20 is the most frequently-tabulated age, namely 7 patients. Many references state that the group range in which hydatidiform mole occurs generally falls at the extreme reproductive age. Its distribution is usually depicted as the $\mathrm{J}$ curve. However, this research results in a rather different distribution; it is depicted in the parabola curve.

It was found that hydatidiform mole occurred most in the 2-5 parity group (48\%). Only $4 \%$ occurred in the 6 or over parity group. In general, this distribution showed an enlarging curve that concurrently increased along with the increase in parity but suddenly lowered down as it reached at the 5 parity. ${ }^{9}$

The data shows that the length of pregnancy examined based on the fundus uteri height was bigger than that based on the last menstruation period. This fits the description of hydatidiform mole in general; $50 \%$ of hydatidiform mole uterine is much larger than the real length of pregnancy. The difference in the high risk group is big enough (6.76 weeks) whereas the one in the low risk group is small (2.40 weeks). These two differences are statistically significant $(\rho<0.05)$

Forty to fifty percent of the patients with complete hydatidiform mole showed an enlargement of uterus more than 4 weeks, which differed from that of the last menstruation period. ${ }^{10-13}$ Uterine enlargement was caused by the expansion of hyperplasia tropoblast and the bleeding of uterine cavity. Although this uterine enlargement - compared to the real length of pregnancy - was a regular clinic manifestation, $15 \%$ to $40 \%$ of the patients originally had a small uterine than gestational age.

Average $\mathrm{T}_{3}$ concentration in this research is $2.22 \pm$ $1.11 \mathrm{ng} / \mathrm{ml}$ whereas that of $\mathrm{T}_{4}$ is $18.87 \pm 6.95 \mathrm{ug} / \mathrm{ml}$ (normally $\mathrm{T}_{3}$ range is $0.8-2 \mathrm{ng} / \mathrm{ml}$, and $\mathrm{T}_{4}$ range $4-$ $12 \mathrm{ng} / \mathrm{dl}$ ). The two values were above the normal ones. Clinical evidence of hyperthyroid presence as an indicator of complete hydatidiform mole was found in $2 \%$ to $7 \%$ percent of the patients. ${ }^{14,15}$ They showed symptoms and signs of enlarging thyroid, tachycardi, febris, and tremor, and critical thyroid sometimes appeared. The evidence that hCG concentration proves as a thyrotropic factor in stimulating the surge of thyrotoxicosis is still a question for further research.

It was found that there was no correlation between the Wayne index value and the grouping of patients with hydatidiform mole $(\rho>0.05)$. However, the Wayne index indicated the presence of more thyroid in the high risk group (85.7\%) than in the low risk group $(14.3 \%)$. The Kariadi index showed that $60 \%$ of hydatidiform mole patients suffered euthyroid and $40 \%$ thyrotoxicosis. Sixteen patients $(53.3 \%)$ with euthyroid and 14 patients (70\%) with thyrotoxicosis fell in the high risk criteria. It could be also seen that, based on the Kariadi Index, the number of thyrotoxicosis patients is larger than that of euthyroid ones although this significant difference cannot be proved statistically $(\rho>0.05)$.

HCG is a glycoprotein hormone that consists of two subtypes: $\alpha$ and $\beta$. The $\alpha$ hCG type is like the glycoprotein pituitary hormone while the other one is unique and different from all other hormones. This hormone is produced by the trophoblast tissue when a patient is pregnant and trophoblast attacks her. A little amount of this hormone is also produced by a certain type of carcinoma tissue. The main function of $\beta$ hCG hormone is to increase the progesterone release by corpus luteum of ovarium. This research shows that average $B$ hCG concentration that happened to the high risk group fell within this range: $56,863.50 \pm$ $53,722.77 \mathrm{mIU} / \mathrm{ml}$ and the low risk group: $16,793.09$ $\pm 25,181.70 \mathrm{mIU} / \mathrm{ml}$. In this research, average $\beta$ hCG concentration prior to evacuation showed a statistically significant difference and whether or not it developed 
into gestational trophoblastic tumor $(\rho<0.05)$. The pre-evacuation $B$ hCG concentration of hydatidiform mole patients that became gestational trophoblastic tumor was higher. It could also noticed that $58.8 \%$ of the patients with $\beta$ hCG concentration over 50,000 $\mathrm{mIU} / \mathrm{ml}$ then suffered gestational trophoblastic tumor. Only $21.2 \%$ of the patients showed a $\beta$ hCG concentration less than $50,000 \mathrm{mIU} / \mathrm{ml}$.

The analysis of statistical logistic regression showed that the $B$ hCG serum concentration variable and presence or absence of other medical factors played a role in causing gestational trophoblastic tumor to develop $(\rho<0.05)$. In general all these variables affected the development of gestational trophoblastic tumor as shown by the $\rho$ value of 0.032 . A further analysis showed that only the $\beta$ hCG constituted a dominant factor $(\rho=0.02)$.

The NETDC prognostic scores showed that $50 \%$ of high risk hydatidiform mole cases developed into malignancy cases whereas $10 \%$ of those of low risk ones developed into the malignancy.
The gestational trophoblastic tumor did not only develop from hydatidiform mole, but also from cases of pregnancies and post-abortus. Several prognostic scores were created as a means of predicting the acuteness of post-hydatidiform mole. Bagshawe and WHO pioneered the development of these prognostic scores. In general, it is agreed that $19 \%$ to $30 \%$ of high risk hydatidiform mole cases will develop into malignancy cases while that of low risk constitute 5\% to $10 \%$. This study shows that the presence of gestational trophoblastic tumor in the high risk group is nine times higher than that of the low risk group. (Confidence interval: $1.769-45.786$ ).

The average time intervals between the hydatidiform mole diagnosis and the finding of gestational trophoblastic tumor for all patients was $10.00 \pm 7.28$ months: the average of $6.00 \pm 2.83$ months for the high risk group and $10.53 \pm 7.57$ months for the low risk group $(\rho=0.426)$. It could be seen that the 12month observation on the high risk group demonstrated a lower survival rate than the low risk group (40\% : $50 \%)$.

Table 4. NETDC prognostic scores of gestational trophoblastic tumor

\begin{tabular}{|c|c|c|c|c|c|}
\hline \multirow{2}{*}{ Type of hydatidiform mole } & \multicolumn{4}{|c|}{ Gestational trophoblastic tumor } & \multirow{2}{*}{$\rho$ value } \\
\hline & \multicolumn{2}{|c|}{ Yes $(n=17)$} & \multicolumn{2}{|c|}{ No $(n=33)$} & \\
\hline $\begin{array}{l}\text { Complete } \\
\text { Partial }\end{array}$ & $\begin{array}{r}17 \\
0\end{array}$ & $\begin{array}{r}34.7 \\
0.0\end{array}$ & $\begin{array}{r}32 \\
1\end{array}$ & $\begin{array}{r}65.3 \\
100.0\end{array}$ & 1.00 \\
\hline $\begin{array}{l}\text { Uterine enlargement } \\
\text { Same / less } \\
\text { More than one month } \\
\text { More than two months } \\
\text { More than three months }\end{array}$ & $\begin{array}{l}3 \\
4 \\
7 \\
3\end{array}$ & $\begin{array}{l}23.1 \\
22.2 \\
46.7 \\
75.0\end{array}$ & $\begin{array}{r}10 \\
14 \\
8 \\
1\end{array}$ & $\begin{array}{l}76.9 \\
77.8 \\
53.3 \\
25.0\end{array}$ & 0.118 \\
\hline $\begin{array}{l}\beta \text { hCG value }(\mathrm{mIU} / \mathrm{ml}) \\
\text { Less than } 50,000 \\
50,000-100,000 \\
100,000-1,000,000\end{array}$ & $\begin{array}{l}6 \\
6 \\
5\end{array}$ & $\begin{array}{l}18.8 \\
50.0 \\
83.3\end{array}$ & $\begin{array}{r}26 \\
6 \\
1\end{array}$ & $\begin{array}{l}81.3 \\
50.0 \\
16.7\end{array}$ & $0.004^{*}$ \\
\hline $\begin{array}{l}\text { Lutein cyst } \\
\text { Not available }\end{array}$ & 17 & 34.0 & 33 & 66.0 & \\
\hline $\begin{array}{l}\text { Age (years) } \\
20-40 \\
\text { Less than / same as } 20 \\
\text { More than / same as } 40\end{array}$ & $\begin{array}{l}5 \\
8 \\
4\end{array}$ & $\begin{array}{l}25.0 \\
36.4 \\
50.0\end{array}$ & $\begin{array}{r}15 \\
14 \\
4\end{array}$ & $\begin{array}{l}75.0 \\
63.6 \\
50.0\end{array}$ & 0.432 \\
\hline $\begin{array}{l}\text { Related factors } \\
\text { None } \\
\text { One or more }\end{array}$ & $\begin{array}{r}2 \\
15\end{array}$ & $\begin{array}{l}11.8 \\
45.5\end{array}$ & $\begin{array}{l}15 \\
18\end{array}$ & $\begin{array}{l}88.2 \\
54.5\end{array}$ & $0.017^{*}$ \\
\hline
\end{tabular}

Data are presented in percentage $(\%)$

*Univariate logistic regression 
Hydatidiform mole are treated by the evacuation of mole tissues and close follow up examination of $\beta$ hCG concentration quantitatively. Approximately 90\% of complete hydatidiform mole cases and 90\%95\% of partial hydatidiform mole cases showed spontaneous regression without being treated with chemotherapy. In this study, $82 \%$ of the patients were treated by evacuate, namely curettage, $16 \%$ by hysterectomy, and $2 \%$ by a combined curettagehysterectomy. After the treatment of curettage, 15 patients $(36.6 \%)$ then suffered gestational trophoblastic tumor and $25 \%$ of hysterectomized patients experienced the malignancy too. Hysterectomic treatments did not prevent the disease from developing. Two patients $(25 \%)$ who were hysteroctomized still suffered gestational trophoblastic tumor. After curettage, 15 patients $(36.6 \%)$ experienced the malignancy of the disease. No malignancy occurred to the patients who were treated with curettage followed by hysterectomy.

\section{Summary}

Predictive or prognostic score of post-hydatidiform mole based on the high- and low-risk grouping was still high. The malignancy experienced by patients of the high risk group is nine times higher than those of the low risk group. Special effort to detect this malignancy as early as possible and thus reduce the number of the high risk patients is crucial; it will decrease the number of diseases and death caused by complication and/or malignancy.

\section{REFERENCES}

1. Bagshawe KD. Trophoblastic tumour : Diagnostics methods, epidemiology, clinical features and management. In : Monaghan JM, Morrow CP, Tattersall MH. Gynecologic oncology fundamental principles and clinical practise. $2^{\text {nd }}$ ed. Edinburg : Churchill Livingstone; 1992.p.1027-43
2. Martaadisubrata D. Problematik penyakit trofoblas ditinjau dari epidemiologi serta pengelolaannya. Bandung : Universitas Padjadjaran, 1980 : 1-130

3. Paradinas FJ. Pathology and classification of trophoblastic tumors. In: Coppleson M. Gynecologyc oncology. $2^{\text {nd }}$ ed. London: Longman Group Ltd; 1992.p.1013-26

4. Hidayat YM, Martaadisubrata D, Bratakoesoema DS. Peranan faktor risiko terjadinya keganasan pascamola hidatidosa di RSHS Bandung 1989-1990. Bandung : Kumpulan makalah KOGI X, 1996:154-64

5. DiSaia PJ, Creasman WT. Clinical gynecologic oncology. $3^{\text {rd }}$ ed. Washington DC: The CV Mosby Company; 1989:214-41

6. Chin HG. On call obstetric and gynecology. $1^{\text {st }}$ ed. Philadelphia : WB Saunders Company; 1997:229-38

7. Sasotya S, Bratakoesoema D. Pengalaman penggunaan sistem skoring sebagai penduga keganasan pascamola hidatidosa. Bandung : Kumpulan naskah ilmiah PTP POGI X Ujung Pandang 1997 : 227-38

8. O'Quinn AG, Barnard DE. Gestational trophoblastic disease. In : De Cherney AH, Pernoll ML. Current obstetric and gynecologic diagnosis and treatment. $8^{\text {th }}$ ed. Norwalk : Appleton \& Lange; 1994.p.967-76

9. Parazzini F, Mangili G, Vecchia LC. Risk factor for gestational disease : A separate analysis of complete and partial hydatidiform moles. Obstet Gynecol 1991; 78: 1039-44

10. Kurnia K. Hubungan antara defisiensi vitamin A dengan molahidatidosa. Jakarta : Bagian Obstetri dan Ginekologi Fakultas Kedokteran Universitas Indonesia; 1991

11. Kurnia K, Andriono, Asikin N. A case control study of vitamine A level in hydatidiform mole. Med J Indones 1997; 6: 153-7

12. Parazzini F, Vecchia LC, Mangili G. Dietary factors and risk of trophoblastic disease. Am J Obstet Gynecol 1988; 158: 93-9

13. Brinton LA, Wu BZ, Wang W. Gestational trophoblastic disease : A case-control study from the People's Republic of China. Am J Obstet Gynecol 1989; 161: 121-7

14. Berkowitz RS, Cramer DW, Bernstein MR. Risk factors for complete molar pregnancy from a case-control study. Am J Obstet Gynecol 1985; 152: 1017-20

15. Meizner I, Leiberman JR, Insler V. Risk factors for gestational trophoblastic neoplasia. Am J Obstet Gynecol 1986; 155: 456-7 